\title{
Jual Beli Online Dengan Sistem Dropship Dalam Perspektif Islam
}

\author{
Nur Fadhillah ${ }^{1 *}$, Zumhur Alamin $^{2}$ \\ 1) Institut Agama Islam Qomaruddin Gresik \\ 2) Institut Agama Islam Muhammadiyah Bima \\ *Corresponding Author: fadilaabdullah@gmail.com
}

\begin{abstract}
ABSTRAK - Seiring berjalannya waktu jual beli online mulai berkembang dalam hal model transaksinya seperti penggunaan sistem dropship. Jual beli dengan sistem dropship ini menjadi salah satu alternatif yang dipilih dikarenakan tidak memerlukan modal besar bahkan tanpa modal sekalipun. Transaksi jual beli online dengan sistem dropship setelah dikaji dari sisi rukun dan syarat jual beli Islam telah memenuhi rukun akad dalam syariah. Sedangkan Pada sisi kepemilikan atas objek barang dalam praktik jual beli sistem dropship memiliki dua pendapat, yaitu: pertama, diperbolehkan dengan catatan penjual mendapatkan ijin dari pemilik barang dan penjual dapat menghadirkan barang tersebut. Kedua dilarang, karena penjual menjual barang bukan miliknya/ barang masih berada pada pemiliknya (supplier).
\end{abstract}

Kata Kunci - Jual Beli; Sistem Dropship; Perspektif Islam

\begin{abstract}
Over time, online trading began to develop in terms of transaction models such as the use of the dropship system. Trading with the dropshipping is one of the alternatives chosen because it does not require large capital even without capital. Online trading with the dropshipping after being studied in terms of the pillars and conditions of Islamic trade have fulfilled the pillars of the contract in sharia. While on the ownership side of the object of goods in the practice of trading with the dropship system has two opinions, namely: first, it is permissible provided the seller obtains permission from the owner of the goods and the seller can present the goods. Second, it is prohibited, because the seller sells goods that do not belong to him/the goods are still with the owner (supplier).
\end{abstract}

Keywords - Trade; Dropshipping; Islamic Perspective

\section{PENDAHULUAN}

Jual beli merupakan suatu perjanjian tukar menukar benda atau barang yang mempunyai nilai sukarela di antara kedua belah pihak, yang satu menerima benda-benda dan pihak lain yang menerimanya sesuai dengan perjanjian atau ketentuan yang telah dibenarkan syara' dan disepakati. ${ }^{1}$ Jual beli dianjurkan seperti firman Allah SWT di dalam surat Al Baqarah ayat 198 yang berbunyi:

${ }^{1}$ Ahmad Azhar Basyir, Asas-asas Hukum Muamalat (Hukum Perdata Islam), (Yogyakarta: UII Press, 2012), hlm. 11. 


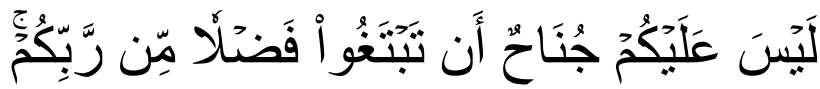

Terjemahan: "Bukanlah suatu dosa bagimu mencari karunia dari Tuhanmu."2

Jual beli yang diterapkan oleh masyarakat saat ini tidak seperti jual beli yang diterapkan oleh masyarakat pada zaman dahulu, hal ini dikarenakan banyak faktor yang mempengaruhinya, diantaranya adalah perkembangan teknologi yang ada. Salah satu bentuk nyata perkembangan teknologi adalah dengan adanya internet.

Perkembangan internet memberi pengaruh dalam segala aspek kehidupan manusia. Internet membantu manusia dalam berinteraksi, berkomunikasi, bahkan dalam aktivitas jual beli dengan orang lain di seluruh dunia dengan mudah dan cepat yang dapat dilakukan kapanpun dan dimanapun. Dengan adanya internet memudahkan dalam interaksi jual beli online, dimana dalam jual beli antara penjual dan pembeli melakukan kegiatan transaksi tanpa bertatap muka, melainkan melalui media internet.

Seiring berjalannya waktu jual beli online mulai berkembang dalam hal model transaksinya seperti penggunaan sistem dropship. Jual beli dengan sistem dropship ini menjadi salah satu alternatif yang dipilih oleh masyarakat Indonesia dalam melakukan transaksi jual beli online dikarenakan tidak memerlukan modal besar bahkan tanpa modal sekalipun. Sistem transaksi dropship merupakan bagian dari jenis bisnis online afiliasi, dimana pelaku bisnis dropship memasarkan produk orang lain tanpa perlu memiliki stok barang maupun menyediakan tempat untuk stok barang, melainkan hanya mempromosikan produk melalui media online dengan memasang foto, deskripsi barang dan harga.

Jual beli sistem dropship ini dilakukan dengan menerima pesanan dan pembayaran barang dari customer, kemudian pesanan dan pembayaran sesuai harga jual diteruskan kepada Dropshipper (supplier/distributor) yang mempunyai stok barang dan pengirimannya dicantumkan nama penjual.

Sistem dropship di Indonesia mendapat banyak respon yang berbeda dari masyarakat Indonesia, baik yang setuju maupun yang tidak setuju. Perbedaan ini menimbulkan perdebatan dalam perspektif hukum Islam mengenai boleh tidaknya model transaksi ini.

Berdasarkan pemaparan di atas, penulis merasa tertarik untuk menulis artikel yang berkaitan dengan sistem dropship dalam jual beli di media online ditinjau dari nash dan maslahahnya.

2 Tim Penyusun Kementerian Agama Republik Indonesia, Tikrar Al-Qur'an Hafalan Tajwid dan Terjemah, (Bandung: PT Sygma Examedia Arkanleema, 2017), hlm. 31.

J-ESA (Jurnal Ekonomi Syariah) 


\section{KAJIAN TEORI}

\section{Dasar Hukum Jual Beli dalam Islam}

Jual beli hukum asalnya jâiz atau mubah/boleh (halal) berdasarkan dalil dari al-Quran, hadits dan ijma' para ulama. Dalam Islam, jual beli dianjurkan seperti firman Allah SWT dalam potongan surah Al-Baqarah ayat 275:

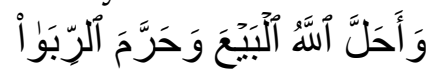

Terjemahan: "...Padahal, Allah telah menghalalkan jual beli dan mengharamkan riba...." 3

Dalam surah An-Nisa ayat 29, Allah SWT juga berfirman:

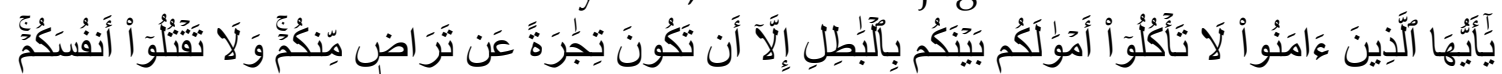

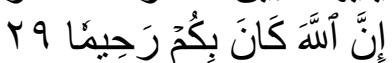

Terjemahan:"Wahai orang-orang yang beriman! Janganlah kamu saling memakan harta sesamamu dengan jalan yang batil (tidak benar), kecuali dalam perdagangan yang berlaku atas dasar suka sama suka di antara kamu. Dan janganlah kamu membunuh dirimu. Sungguh, Allah Maha Penyayang kepadamu." 4

Selain ayat al-Qur`an sebagai sumber hukum utama umat Islam dalam menjalani setiap kegiatan ibadah dan bermuamalah, hadist juga digunakan sebagai sumber hukum kedua umat Islam, dimana banyak pula hadist yang menjelaskan tentang jual beli. Adapun landasan jual beli yang berasal dari hadist Rasulullah saw adalah sebagai berikut:

$$
\text { تر اض عن انمالبيع }
$$

Terjemahan: "Sesungguhnya sahnya jual beli atas dasar kerelaan" (riwayat ibn Hibban dan Ibn Majah) ${ }^{5}$

Selain itu, dalam hadis Nabi saw lainnya juga disebutkan sebagai berikut:

$$
\text { رو اه) ,مبرور بيع وكل, بيد الرجل عمل:اطيب:قل الكسب ای:سال.م.ص.النبي ان رافع بن رفاعة عن }
$$

Terjemahan: "dari rifa'ah bahwasannya Nabi saw. Ditanya apakah pencaharian yang lebih baik? Jawabnya: bekerja dan tiap-tiap jual beli yang mabrur."

Selain Al-Qur'an dan Hadits Nabi sebagai sumber hukum, juga terdapat sumber hukum ketiga yakni Ijma' para ulama yang bisa dijadikan sumber

\footnotetext{
3 Ibid., hlm. 47.

4 Ibid., hlm. 83.

${ }^{5}$ Hendi Suhendi, Fiqih Muamalah, (Jakarta: PT. Raja Grafindo Persada, 2007), hlm. 70.
} 
hukum dan para ulama telah sepakat bahwasanya hukum jual beli adalah diperbolehkan. ${ }^{6}$

Dari hadits di atas, peneliti mengambil kesimpulan bahwa hukum jual beli diperbolehkan apabila tidak ada unsur riba di dalamnya, jual beli harus berdasar pada kerelaan kedua belah pihak atau tanpa adanya unsur paksaan, tanpa tipu daya dan tidak merugikan orang lain.

\section{Syarat dan Rukun Jual Beli \\ Rukun Jual Beli}

Jual beli dikatakan sah dan halal apabila telah memenuhi semua syarat dan rukun yang telah ditentukan dalam Islam. Menurut rukun jual beli terdapat beberapa pendapat para ulama, diantaranya:

1. Menurut Mazhab Hanafi, rukun jual beli hanya ada satu, yaitu Ijab (ungkapan dari pembeli) dan Qabul (ungkapan dari penjual). Menurut mazhab ini, rukun jual beli hanyalah kerelaan dari kedua belah pihak yang melakukan transaksi. ${ }^{7}$

2. Menurut Jumhur Ulama, rukun jual beli terdiri dari empat, yaitu:

a. Adanya orang yang melakukan akad (penjual dan pembeli).

b. Adanya shigat (lafadz, Ijab dan Qabul).

c. Adanya barang yang diperjualbelikan.

d. Ada nilai tukar pengganti barang. 8

\section{Syarat Jual Beli}

Syarat jual beli, antara lain:

1. Akad

Syarat akad dalam jual beli menurut beberapa ulama, diantaranya:

a. Menurut Hanafiyah, syarat akad jual beli adalah sebagai berikut:

1) Terlaksananya ijab qabul tidak harus diungkapkan dengan perkataan tertentu, tapi cukup dengan tujuan dan makna yang dihasilkan.

2) Berlangsung dalam majelis akad.

3) Memenuhi syarat kemestian yaitu tidak adanya hak khiyar yang memberikan pilihan kepada masing-masing pihak, baik membatalkan maupun meneruskan jual beli.

4) Memenuhi syarat shigat yang bersifat umum.

5) Memenuhi syarat dalam pelaksanaan akad. ${ }^{9}$

${ }^{6}$ Dimyuddin Djuaini, Pengantar Fiqh Muamalah, (Yogyakarta: Pustaka Pelajar, 2008), hlm. 73.

${ }^{7}$ Rachmat Syafi'i, Figh Muamalah, (Bandung: Pustaka Setia, 2006), hlm. 35.

8 M. Ibnu Qasim, Fathu Al-Qarib Al-Mujib, (t.t. Syirkah Al-Ma arif. T.t), hlm. 30. hlm. 121.

${ }_{9}^{9}$ Gufron Al-Mas'adi, Fiqh Muamalah Kontekstual, (Jakarta: Raja Grafindo Persada, 2002), 
b. Menurut Ulama Malikiyah, syarat akad dalam jual beli yaitu tempat dan akad harus bersatu, tidak ada jeda antara pengucapan Ijab dan Qabul, dan tidak terjadi perpisahan antara penjual dan pembeli.

c. Menurut ulama Hanabilah, syarat akad dalam jual beli adalah berada pada tempat yang sama, tidak terpisah antara ijab dan qabul, tidak dikaitkan dengan sesuatu yang tidak berkaitan langsung dengan kegiatan jual beli.

d. Menurut syafiiyah, syarat akad dalam jual beli adalah:

1) Berhadap-hadapan, ijab dan qabul tidak terpisah, bersesuaian antara ijab dan qabul.

2) Ditunjukkan kepada seluruh badan yang berakad.

3) Qabul yang diucapkan oleh orang yang dituju dalam ijab haruslah orang yang diajak bertransaksi atau wakil yang berkuasa.

4) Harus menyebutkan barang dan harganya.

5) Ketika mengucapkan sighat harus disertai dengan niat.

6) Pengucapan Ijab dan Qabul haruslah sempurna.

7) Tidak mengkaitkan akad dengan sesuatu yang lain yang tidak ada hubungannya dengan transaksi jual beli.

8) Tidak dikaitkan dengan waktu.

2. Pelaku (Aqid)

Syarat pelaku menurut beberapa para ulama, antara lain:

a. Menurut Malikiyah, syarat pelaku (aqid) adalah penjual dan pembeli harus mumayiz (dewasa), keduanya merupakan pemilik barang atau yang mewakili, keduanya dalam keadaan suka rela, sadar dan dewasa.

b. Ulama Hanabilah mensyaratkan pelaku (aqid) adalah sebagai berikut:

1) Pelaku jual beli harus baligh dan berakal, kecuali atas barang yang sepele atau telah mendapat izin dari walinya dan memberikan unsur kemaslahatan.

2) Ada keridhaan antara penjual dan pembeli, ikhlas dan tanpa adanya tekanan dari salah satu pihak. Ulama Hanabilah menghukumi makruh seseorang yang melakukan transaksi jual beli dalam keadaan yang terpaksa atau karena terdesak kebutuhan dengan harga yang tidak lazim. ${ }^{10}$

c. Menurut Ulama Syafi'iyah, syarat pelaku (Aqid) jual beli adalah:

1) Dewasa dan sadar.

2) Tidak terpaksa.

10 Nasroen Haroen, Figh Muamalah, (Jakarta: Gava Media Pramata, 2000), hlm. 118. 
3) Islam, orang kafir tidak sah membeli kitab Al-Qur'an, Hadis atau budak beragama Islam.

4) Pembeli bukan musuh, umat Islam dilarang melakukan transaksi dengan orang yang menjadi musuh muslim terlebih berkaitan dengan sengaja apapun yang dapat menghancurkan umat Islam. ${ }^{11}$

\section{Pengertian Dropship}

Dropship adalah metode berjualan, dimana penjual tidak menyimpan stok barang dan ketika penjual mendapatkan pesanan dari pembeli, penjual tersebut akan meneruskan pesanan dan detail pengiriman barangnya ke distributor/supplier/produsen yang telah bekerjasama dengan mereka. ${ }^{12}$

Dalam pengertian lainnya, Dropship adalah suatu sistem jual beli, dimana penjual menjual produk yang tidak dimiliki dan tidak mempunyai persediaan stok barang. Penjual hanya bermodalkan foto barang dari dari supplier, yang kemudian dipasarkan kepada konsumen, jika terjual maka penjual membeli barang dari supplier dan supplier akan mengirimkan barangnya dengan atas nama penjual. Sistem ini sesuai bagi kalangan yang baru memulai usaha tetapi terbatas dalam hal pengalaman dan minimnya modal, karena tidak perlu menggunakan modal besar dan risiko dalam sistem dropship ini relatif sangat kecil. ${ }^{13}$ Ada 3 pihak yang terlibat dalam transaksi sistem dropship, yaitu Dropshipper, Penjual, dan Pembeli. Dropshipper adalah pemilik barang, baik dia produsen, toko, atau agen. Sedangkan pihak yang menawarkan barang itu penjual. ${ }^{14}$

1. Mekanisme Sistem Dropship

Dalam kegiatan jual beli dengan sistem dropship. Pertama, penjual memasang iklan produk yang dijual di website, blog, media sosial (facebook, twitter, whatsapp), iklan baris, forum, marketplace (Shopee, Lazada, Tokopedia, dan lain-lain) dengan menampilkan deskripsi dan detail produk dengan jelas. Kedua, konsumen mengakses situs tertentu dengan cara masuk ke alamat website toko online yang menawarkan penjualan barang tersebut. Setelah masuk dalam situs tersebut, konsumen dapat melihat pilihan menu dan memilih barang yang ingin dibeli. Misalnya, jam tangan, klik jam tangan, merk yang diinginkan, klik harga yang sesuai dan jumlah

11 Ibid., hlm. 119.

12 Adi Nugroho, E-Commerce Memahami Perdagangan di Dunia Maya Cetakan 1, (Bandung: Informatika, 2006), hlm. 9.

13 Purnomo Hadi, Jualan Online Tanpa Repot Dengan Dropshipping, (Jakarta: PT. Elex Media Komputindo, 2012), hlm 1.

14 Derry Iswidharmanjaya, Dropshipping Cara Mudah Bisnis Online, (Jakarta: PT. Elex Media Komputindo, 2012), hlm. 5.

J-ESA (Jurnal Ekonomi Syariah) 
barangnya, kemudian memilih jasa pengiriman (berkaitan dengan ongkos kirim) dan metode pembayarannya, berikutnya membuat pesanan. Selanjutnya penjual akan mengirimkan nomor rekening atau pembayaran ke nomor kontak pembeli, selanjutnya konsumen mengisi identitas dan alamat pengiriman, setelah itu konsumen tinggal menunggu kedatangan barangnya. Ketiga, penjual akan mengirimkan identitas diri beserta alamat pengiriman pembeli kepada produsen/distributor/supplier/Dropshipper dan juga melakukan transfer sejumlah harga barang berikut ongkos kirimnya. Keempat, produsen/distributor/supplier akan mengirimkan barang kepada pembeli dengan mengatasnamakan pengirim adalah penjual atau nama toko penjual. ${ }^{15}$

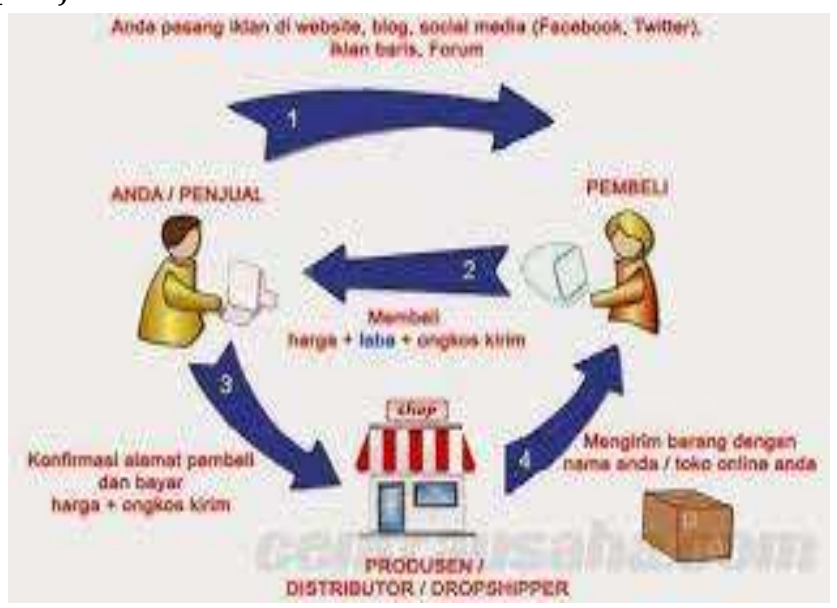

Gambar 1. Skema Mekanisme Sistem Dropship16

2. Kelebihan dan Kekurangan Sistem Dropship ${ }^{17}$

a. Kelebihan Sistem Dropship ${ }^{18}$

1) Tidak memerlukan persiapan yang rumit untuk memulainya, seperti layaknya membuka toko.

2) Penjual tidak perlu membeli produk terlebih dahulu, sehingga tidak membutuhkan modal. Jika ada pembeli yang melakukan pembayaran atas barang yang dibeli, penjual tinggal meneruskan uang pembayaran tersebut kepada produsen/distributor/supplier, tentunya setelah dipotong jumlahnya sebagai keuntungan penjual tentunya.

${ }_{15}$ Misbahuddin, E-Commerce dan Hukum Islam, (Makassar: Alauddin Univerity Press, 2012), hlm. 24.

16 Izna Faruq, Sistem Cara Kerja Bisnis Dropship Serta Definisi dan Keuntungannya, diakses dari centrausaha.com, pada tanggal 1 September 2021, pukul 16.00 WIB.

17 Purnomo Hadi, Jualan Online Tanpa Repot Dengan Dropshipping, Op.Cit., hlm 4.

${ }^{18}$ Ibid., hlm 4. 
3) Penjual tidak perlu menyewa toko karena bisnis dapat dilakukan di rumah dan juga tidak perlu menyediakan tempat untuk menyimpan barang.

4) Transaksi dapat dilakukan dimana saja dan kapan saja.

5) Penjual tidak khawatir barang tidak laku atau rusak.

6) Penjual tidak repot mengemas barang dan mengirimkan barang ke konsumen. Karena produsen/distributor/supplier yang melakukannya.

7) Penjual tidak perlu membayar gaji karyawan, mengeluarkan biaya pengemasan, transportasi dan lainnya. Hanya mengeluarkan biaya pulsa untuk mengakses internet.

8) Penjual hanya bermodalkan katalog, foto produk-produknya untuk digunakan sebagai sarana promosi.

9) Tidak menyita banyak waktu karena urusan produksi, pengemasan, dan pengiriman barang dilakukan oleh pihak Produsen/Distributor/Supplier/Dropshipper.

10) Persentase keuntungan ditentukan oleh penjual sendiri.

b. Kekurangan Sistem Dropship ${ }^{19}$

1) Penjual kesulitan dalam memantau stok barang.

2) Penjual kesulitan dalam menjawab komplain dari konsumen.

3) Laba yang diperoleh tidak terlalu besar.

4) Adanya resiko kalah dalam bersaing dengan reseller.

\section{Sistem Dropship dalam Perspektif Islam}

Pada prinsipnya Allah SWT menghalalkan jual beli dan mengharamkan riba. Dengan demikian, asal dalam bermuamalah termasuk di dalamnya jual beli adalah boleh, kecuali ada dalil yang menunjukkan keharamannya. Firman Allah SWT dalam surah Al-Baqarah ayat 275 dan surah Al-Maidah ayat 1:

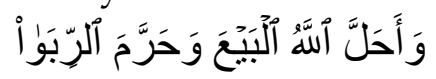

Terjemahan: “...Padahal, Allah telah menghalalkan jual beli dan mengharamkan riba...." 20

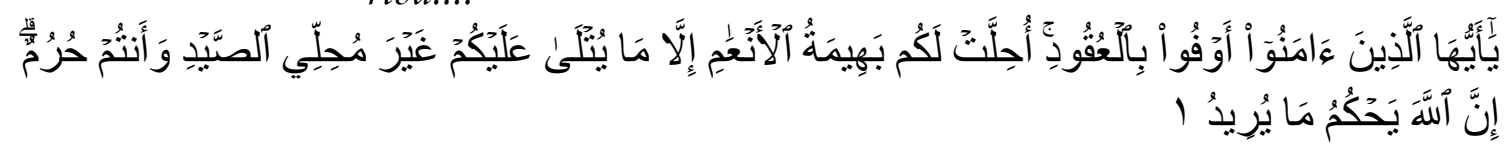

Terjemahan: "Wahai orang-orang yang beriman! Penuhilah janji-janji. Hewan ternak dihalalkan bagimu kecuali yang akan disebutkan kepadamu, dengan tidak menghalalkan berburu ketika kamu sedang berihram (haji

19 Tim Wahana Komputer, Membangun Usaha Bisnis Dropshipping, (Jakarta: PT. Elex Media Komputindo, 2013), hlm. 20.

20 Tim Penyusun Kementerian Agama Republik Indonesia, hlm. 47. 
atau umrah). Sesungguhnya Allah menetapkan hukum sesuai dengan yang Dia kehendaki."21

Dalam kaidah fiqiyah, pokok dalam urusan muamalah itu diperbolehkan atau halal sampai ada dalil yang menunjukkan atas pengharamannya. Adapun beberapa prinsip yang perlu diperhatikan dalam akad jual beli adalah sebagai berikut:

1. Atas dasar kerelaan diantara keduanya

Hal ini terdapat dalam surah An-Nisa ayat 29 yang terjemahannya:

"Wahai orang-orang yang beriman! Janganlah kamu saling memakan harta sesamamu dengan jalan yang batil (tidak benar), kecuali dalam perdagangan yang berlaku atas dasar suka sama suka di antara kamu. Dan janganlah kamu membunuh dirimu. Sungguh, Allah Maha Penyayang kepadamu". 22

Adanya kerelaan dari kedua belah pihak (aqid). Kerelaan tersebut dapat dilihat dari ijab dan qabul yang dilakukan. Pernyataan ijab dan qabul dapat berupa ucapan lisan, tulisan/surat-menyurat, dan dapat juga berupa perbuatan yang telah menjadi kebiasaan dalam ijab dan qobul.23 Dalam hal ini akad yang dilakukan dalam sistem dropship adalah sesuai, karena akad dilakukan melalui tulisan.

2. Tidak mengandung unsur riba

Riba dapat timbul dalam pinjaman yang disebut sebagai riba dayn dan dapat pula timbul dalam perdagangan yaitu riba bai'. Riba bai' sendiri terdiri dari dua jenis, yaitu riba fadl, yakni riba karena pertukaran barang sejenis, tetapi jumlahnya tidak seimbang, dan riba nasiah, yakni riba karena pertukaran barang sejenis dan jumlahnya dilebihkan karena melibatkan jangka waktu. Allah SWT dalam Al-Qur'an surah Al-Baqarah ayat 278-279 melarang riba sesuai dengan firman-Nya:

"Wahai orang-orang yang beriman! Bertakwalah kepada Allah dan tinggalkan sisa riba (yang belum dipungut) jika kamu orang beriman. Jika kamu tidak melaksanakannya, maka umumkanlah perang dari Allah dan rasul-Nya. Tetapi jika kamu bertobat, maka kamu berhak atas pokok hartamu. Kamu tidak berbuat zalim (merugikan) dan tidak dizalimi (dirugikan)". 24

Berikutnya dalam Al-Qur'an surah Ar-Rum ayat 39, Allah SWT juga berfirman:

\footnotetext{
${ }^{21}$ Ibid., hlm. 106.

22 Ibid., hlm. 83.

23 Haris Maulidi Asnawi, Transaksi Bisnis E-Commerce Perspektif Islam, (Yogyakarta: Magistra Insania Press, 2004), hlm. 78.

24 Tim Penyusun Kementerian Agama Republik Indonesia, hlm. 47.
} 
"Dan sesuatu riba (tambahan) yang kamu berikan agar harta manusia bertambah, maka tidak bertambah dalam pandangan Allah". ${ }^{25}$

3. Tidak terdapat unsur penipuan

Diriwayatkan dari Abu Hurairah ra: Rasulullah SAW pernah lewat dihadapan orang yang sedang menjual setumpuk makanan. Lalu beliau memasukkan tangannya ke dalam tumpukan makanan itu, ternyata tangan beliau mengenai makanan basah di dalamnya. Kemudian beliau bertanya kepada orang itu, "Mengapa ini basah wahai penjual makanan?" Orang itu menjawab, "Makanan yang di dalam itu terkena hujan wahai Rasulullah." Beliau bersabda, "Mengapa tidak kamu letakkan di atasnya supaya diketahui oleh orang yang akan membelinya? Barang siapa menipu, dia bukan dari golonganku."26

Jual beli dengan sistem dropship harus menampilkan secara utuh spesifikasi barang beserta informasi dari barang yang dijual. Kesesuaian barang dan gambar produk yang dipasang sangat diperlukan bagi para konsumen. Dalam praktik jual beli online dengan sistem dropship, barang sebenarnya bisa jadi tidak sesuai dengan foto produk yang ditampilkan. Barang aslinya terkadang terlihat lebih terang atau gelap dari gambar barang yang dipajang. Hal ini dapat terjadi karena perbedaan resolusi handphone dari pembeli, dimana layar handphone dapat menyajikan warna lebih terang atau lebih redup. Oleh karena itu penjual dapat memberikan informasi di deskripsi toko onlinenya bahwa barang yang diperdagangkan 85\%-90\% mirip dengan aslinya karena faktor teknis. ${ }^{27}$

4. Tidak terdapat unsur gharar (spekulasi)

Gharar yaitu jual beli yang mengandung ketidakjelasan yang merugikan salah satu pihak karena barang yang diperjualbelikan tidak dapat dipastikan jumlah dan ukurannya, atau karena tidak mungkin dapat diserah-terimakan. ${ }^{28}$

"Diriwayatkan dari Abu Hurairah r.a: Rasulullah SAW. melarang jual beli dengan cara melempar kerikil kepada barang yang dibelinya (bai' al-hasha) dan melarang menjual barang yang tidak jelas rupa dan sifatnya."29

${ }^{25}$ Ibid., hlm. 408.

${ }^{26}$ Tim Penyusun, Ringkasan Shahih Muslim, (Bandung: PT Mizan Pustaka, 2009), hlm. 512.

${ }_{27}$ Feri Sulianta, Terobosan Berjualan Online Dropshipping ++, (Yogyakarta: Andi Publisher, 2014), hlm. 72.

${ }_{28}$ Ghufron A. Mas'adi, Figh Muamalah Konstektual, (Jakarta: PT Raja Grafindo Persada, 2002), hlm. 133.

${ }^{29}$ Tim Penyusun. hlm. 509. 
Ibnul Qayyim berkata “orang yang menjual sesuatu yang bukan miliknya termasuk jenis jual beli gharar, yang kadang bisa terjadi dan tidak". Ini juga mengandung unsur judi dan taruhan. ${ }^{30}$

Penjual harus memiliki barang yang dijualnya atau mendapat izin dari pemilik barang untuk menjualnya. Dalam jual beli sistem dropship para penjual tidak perlu menyediakan stok barang. ${ }^{31}$ Dalam sistem ini seorang penjual tidak memiliki barang dan tidak pula mengetahui secara fisik produk yang ditawarkan ke konsumen karena barangnya berada di supplier.

Terdapat larangan menjual barang yang tidak dimiliki dan sesuatu yang belum menjadi miliknya, sebagaimana sabda Rasulullah:

"Diriwayatkan dari Ibn Abbas r.a: Rasulullah SAW bersabda, "Barang siapa membeli suatu makanan, janganlah menjualnya, kecuali setelah dia menerimanya dengan sempurna. "Saya kira, hukum ini berlaku untuk semua barang apapun. 32

Dari hadist di atas diketahui terdapat larangan yang tegas, bahwa tidak boleh menjual sesuatu kecuali telah dimiliki sebelum akad, baik dijual tunai maupun tempo. Sistem dropship termasuk sistem jual beli yang penjualnya tidak memiliki barang dan hanya supplier yang memiliki barang tersebut. Kemudian penjual menjual barang miliknya supplier. Ini artinya, penjual menjual barang yang bukan miliknya. Tetapi jika supplier yang memiliki barang meminta kepada penjual untuk menjualkan barangnya, tentu saja hukumnya halal dan penjual tersebut berhak untuk mendapatkan imbalan atas jasa dari menjualkan barang tersebut.

Adapun dalil yang memperbolehkan makelar atau calo adalah di surat Al Maidah ayat 1.

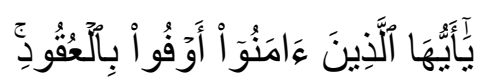

Terjemahan: "Wahai orang-orang yang beriman! Penuhilah janji-janji."33

Pada ayat di atas, Allah SWT memerintahkan orang-orang beriman untuk menyempurnakan akad-akad (janji-janji), termasuk di dalamnya menyempurnakan perjanjian seorang pedagang dengan calo (makelar).

Berdasarkan uraian di atas, maka dapat disimpulkan bahwa tidak ada larangan bagi penjual untuk menjual barang milik orang lain, asalkan mendapatkan izin dari pemilik barang tersebut.

5. Komoditas yang diperjualbelikan bukan yang diharamkan

${ }^{30}$ Asyraf Muhammad Dawabah, Menjadi Pengusaha Muslim, (Jakarta: Pustaka Al-Kautsar, 2005), hlm. 107.

31 Deny Setiawan, Buat Toko Online Sendiri dengan Opencart, (Yogyakarta: Andi Publisher, 2014), hlm. 96.

32 Tim Penyusun........... hlm. 497.

33 Ibid., hlm. 106. 
Objek yang diperjualbelikan, baik berupa jasa atau komoditi harus halal, suci, mempunyai nilai dan manfaat, memiliki kejelasan baik bentuk, fungsi maupun keadaannya, serta dapat diserah terimakan pada waktu, tempat (media) yang telah disepakati. ${ }^{34}$

Diriwayatkan dari Jabir bin Abdillah r.a bahwa dia pernah mendengar Rasulullah SAW bersabda pada waktu tahun penaklukan Makkah, "Sesungguhnya, Allah dan Rasul-Nya telah mengharamkan penjualan tuak, bangkai, babi, dan patung." Lalu beliau ditanya, "Wahai Rasulullah, bagaimana pendapat engkau tentang hukum lemak bangkai karena lemak itu bisa dipakai untuk gemuk perahu, minyak kulit, dan lampu?" Beliau menjawab, "Tidak boleh, lemak bangkai itu hukumnya tetap haram untuk dipergunakan." Kemudian, Rasulullah SAW melanjutkan sabdanya pada waktu itu, "Semoga Allah memerangi orang-orang Yahudi. Sesungguhnya, Allah telah mengharamkan lemak bangkai kepada mereka, tetapi kemudian mereka memasaknya untuk diencerkan. Setelah itu, mereka menjualnya dan uangnya mereka gunakan untuk makan."35

6. Tidak ada pihak yang dirugikan

Jadi disini tidak ada madharat dan tidak memadharatkan, baik penjual maupun pembeli. Dalam transaksi jual beli online dengan sistem dropship, jika dari pihak pembeli terdapat keluhan terhadap barang yang dibeli karena kelalaian atau kesalahan dari pihak penjual, maka pihak penjual dapat menyediakan pelayanan konsumen berupa kotak saran atau web diskusi. Selain itu, tanggung jawab penjual dapat ditunjukkan dengan cara menjawab pertanyaan dari pelanggan, memberikan penjelasan yang ramah dan mengganti barang yang tidak sesuai. ${ }^{36}$

\section{KESIMPULAN}

Transaksi jual beli online dengan sistem dropship setelah dikaji dari sisi rukun dan syarat jual beli dalam Islam, telah memenuhi rukun akad dalam syariah. Sedangkan dari sisi kepemilikan atas objek barang dalam praktik jual beli sistem dropship memiliki dua pendapat, yaitu:

1. Dilarang, karena barang belum sepenuhnya dimiliki oleh penjual dikarenakan barangnya masih ditangan pemiliknya (Produsen/Distributor/Supplier/Dropshipper).

2. Diperbolehkan, meskipun penjual tidak mempunyai stok barang yang akan dijual, tetapi penjual mendapatkan izin dari pemilik barang untuk menjualkan barangnya dan dapat menghadirkan barang yang akan diperjualbelikan, karena dalam jual beli online dengan sistem dropship

${ }^{34}$ Arif Purkon, Bisnis Online Syariah, (Jakarta: Gramedia, 2014), hlm. 31-32.

35 Tim Penyusun........... hlm. 506.

36 Jefferly Helianthusonfri, Sukses Bisnis Toko Online, (Jakarta: PT. Elex Media Komputindo, 2013), hlm. 223. 
prinsipnya adalah penjual sebagai wakil bagi pemiliknya (Produsen/Distributor/Supplier/Dropshipper).

Hal-hal yang dilarang dalam sistem dropship dan harus dihindari bagi penjual yaitu: 1) Kecurangan atau penipuan yang dapat mengurangi kepercayaan calon konsumen atau pelanggan untuk melakukan pembelian. 2) Ketidakjelasan pada barang dan harga. Karena kejelasan atas barang dan harga akan memberikan keamanan dan kenyamanan bagi konsumen dalam melakukan transaksi.

\section{DAFTAR PUSTAKA}

Al-Mas'adi, Gufron. 2002. Fiqh Muamalah Kontekstual. Jakarta: Raja Grafindo Persada.

Asnawi, Haris Maulidi. 2004. Transaksi Bisnis E-Commerce Perspektif Islam. Yogyakarta: Magistra Insania Press.

Basyir, Ahmad Azhar. 2012. Asas-asas Hukum Muamalat (Hukum Perdata Islam). Yogyakarta: UII Press.

Dawabah, Asyraf Muhammad. 2005. Menjadi Pengusaha Muslim. Jakarta: Pustaka Al-Kautsar.

Djuaini, Dimyuddin. 2008. Pengantar Fiqh Muamalah. Yogyakarta: Pustaka Pelajar.

Hadi, Purnomo. 2012. Jualan Online Tanpa Repot Dengan Dropshipping. Jakarta: PT. Elex Media Komputindo.

Haroen, Nasroen. 2000. Fiqh Muamalah. Jakarta: Gava Media Pramata.

Helianthusonfri, Jefferly. 2013. Sukses Bisnis Toko Online. Jakarta: PT. Elex Media Komputindo.

Iswidharmanjaya, Derry. 2012. Dropshipping Cara Mudah Bisnis Online. Jakarta: PT. Elex Media Komputindo.

M. Ibnu Qasim, Fathu Al-Qarib Al-Mujib, t.t. Syirkah Al-Ma arif. T.t.

Mardani. 2011. Fiqh Ekonomi Syariah. Jakarta: Kencana.

Misbahuddin. 2012. E-Commerce dan Hukum Islam. Makassar: Alauddin Univerity Press.

Nugroho, Adi. 2006. E-Commerce Memahami Perdagangan di Dunia Maya Cetakan 1. Bandung: Informatika.

Purkon, Arif. 2014. Bisnis Online Syariah. Jakarta: Gramedia.

Setiawan, Deny. 2014. Buat Toko Online Sendiri dengan Opencart. Yogyakarta: Andi Publisher.

Suhendi, Hendi. 2007. Fiqih Muamalah. Jakarta: PT. Raja Grafindo Persada.

Sulianta, Feri. 2014. Terobosan Berjualan Online Dropshipping ++. Yogyakarta: Andi Publisher.

Syafi'i, Rachmat. 2006. Fiqh Muamalah. Bandung: Pustaka Setia. 
Tim Penyusun Kementerian Agama Republik Indonesia. 2017. Tikrar Al-Qur'an Hafalan Tajwid dan Terjemah. Bandung: PT Sygma Examedia Arkanleema.

Tim Penyusun. 2009. Ringkasan Shahih Muslim. Bandung: PT Mizan Pustaka.

Tim Wahana Komputer. 2013. Membangun Usaha Bisnis Dropshipping. Jakarta: PT. Elex Media Komputindo. 